\title{
Evaluating and modeling ecosystem service loss of coal mining: A case study of Mentougou district of Beijing, China
}

\author{
Feng $\mathrm{Li}^{\mathrm{a}}$, Xusheng Liu ${ }^{\mathrm{b}}$, Dan Zhao ${ }^{\mathrm{a}, *}$, Beibei Wang ${ }^{\mathrm{c}}$, Jiasheng Jin ${ }^{\mathrm{a}}$, Dan $\mathrm{Hu}^{\mathrm{a}}$ \\ a State Key Laboratory of Urban and Regional Ecology, Research Center for Eco-Environment Sciences, Chinese Academy of Sciences, Shuangqing Road 18, \\ Haidian District, Beijing 100085, PR China \\ ${ }^{\mathrm{b}}$ Chinese Academy of Forest Inventory and Planning, State Forestry Administration, Beijing 100714, PR China \\ ${ }^{\mathrm{c}}$ Beijing Municipal Institute of Labour Protection, Beijing 100054, PR China
}

\section{A R T I C L E I N F O}

\section{Article history:}

Received 17 September 2010

Received in revised form 16 December 2010

Accepted 8 January 2011

Available online 28 January 2011

\section{Keywords:}

Ecosystem service

Value estimation

Sustainable development

Coal mining

Beijing

\begin{abstract}
A B S T R A C T
With fast urbanization and industrialization, the unreasonable exploitation of the natural resources has led to some environmental problems in the world. It needs to evaluate the ecological and environmental loss resulted from resource exploitation and set up an effective ecological compensation mechanism to promote the sustainable using of resources. Taking the Mentougou district of West Beijing in China as the case study, comprehensively applying the theory of ecosystem service, ecological economics, social investigation and analysis, and other research methods, the mined coal value and its corresponding loss of ecosystem services in Mentougou district of Beijing, China were evaluated in this paper. According to the research results, the economic value of mined coal resource in Mentougou district was about $\$ 870$ million, and the corresponding loss of ecosystem services caused by coal mining was approximately $\$ 2001$ million, including the loss due to land occupancy by waste coal, mining sink, reclamation for mining waste land, and water and soil loss in the past 50 years. So, in fact, the ecological and environmental loss caused by coal mining was far more than its economic benefits. This article can provide a scientific basis for ecological restoration and compensation of natural resource protection and utilization in other similar areas in China as well as in Western countries.
\end{abstract}

(c) 2011 Elsevier B.V. All rights reserved.

\section{Introduction}

The world is becoming an increasingly urban place. About 65\% of the world's population is expected to live in urban areas by the year 2025 (Barbier, 1994; Costanza et al., 1997). Due to the fast pace of urbanization, natural ecosystems are increasingly replaced by cities. Urbanization promotes rapid social and economic development, but at the same time, leads to many ecological and environmental problems, such as population concentration, traffic jams, housing shortages, resource loss, biodiversity reductions, "heat island" effects, noise, air and water pollution (Daily, 1997; Loomis et al., 2000; Li et al., 2005; McNeely et al., 1990; Norberg, 1999; OECD, 1995; Pearce and Moran, 1994; Seidl and Moraes, 2000; Wang et al., 2004). Human-environmental systems are challenged by current and upcoming ecological and socioeconomic problems all over the world (Ma and Wang, 1984; Wang, 1986; Editorial, 2010; Wang et al., 2010). People are increasingly realizing the importance of the urban sustainable development that will mitigate or eliminate these problems, and many countries

\footnotetext{
* Corresponding author. Tel.: +86 10 62849103; fax: +86 1062849103.

E-mail addresses: zhaodan718100@163.com, lifeng@rcees.ac.cn (D. Zhao).
}

have already enacted strategies to promote urban sustainable development (Li et al., 2008, 2009).

Mentougou district is located at the west Beijing, China, ranging from East longitude $115^{\prime} 25^{\prime} 00^{\prime \prime}$ to $116^{\prime} 10^{\prime} 07^{\prime \prime}$ and North latitude from $39^{\prime} 48^{\prime} 34^{\prime \prime}$ to $40^{\circ} 10^{\prime} 37^{\prime \prime}$, stretching over $62 \mathrm{~km}$ from the East to the West and $34 \mathrm{~km}$ from the North to the South. It totally covers an area of $1455 \mathrm{~km}^{2}, 98.5 \%$ of which is the mountainous region, plain area only accounts for $1.5 \%$. Mentougou district belongs to the middle latitude continental monsoon climate with annual average air temperature of $11^{\circ} \mathrm{C}$ and annual average sunshine of $2470 \mathrm{~h}$. Average annul rainfall is about $563 \mathrm{~mm}$ in this area. The soil of Mentougou district belongs to zone brown soil. Plants in this area are abundant and there are about 1100 kinds of higher plants, belonging to 135 families and 485 genus. The major forest arbor species is birch, aspen and pines and larch. This area also abounds in mineral resources such as coal, limestone granite and so on. The total population of Mentougou district is 236,000 (Mentougou Statistical Bureau, 2006). Mentougou district has the history of excavating coal for more than 100 years. Coal mining has already brought about some ecological and environmental problem to this area, which affected the sustainable development of Beijing region. The costs and benefits to the ecosystem of different human activities may be achieved through the identification of the impacts of human activities and through the quantification of their 
consequences for the supply of ecosystem services (Pinto et al., 2010; Daily, 1999; Daily et al., 2002, 2009; Daily and Matson, 2008; Yapp et al., 2010). Services by ecosystem mean activities offered to the user of ecosystems and they could therefore be measured by the work capacity (Jørgensen, 2010). The evaluation of economic value and its ecological and environmental effect of coal resource exploitation were carried out in this paper. It is useful to provide scientific basis for the optimization of ecosystem services and the establishment of ecological compensate mechanism.

\section{Ecological and environmental influence of coal mining in Mentougou district of Beijing}

\subsection{Landscape damages}

The land occupied by coal waste covers an area of $1.8 \mathrm{~km}^{2}$ in Mentougou district. Landscape destroy is one of the effects of coal resource exploitation and processing. Large amount of exposed coal stack occupies lots of farmlands and destroys the neighbouring landscape. Moreover, the powders coming from coal mining get up with the wind. After it falls to the plants, it affected their nutrients, photosynthesis and production (Gettings et al., 2004; Sandhu et al., 2010).

\subsection{Changes of land use structure}

Due to the coal mining, the area of farmlands in Mentougou district reduced $4965 \mathrm{hm}^{2}$ from 1991 to $1995,2534 \mathrm{hm}^{2}$ from 1995 to 2001 and $437 \mathrm{hm}^{2}$ from 2001 to 2005 . The total decreased area of farmlands is about $7935 \mathrm{hm}^{2}$ from 1991 to 2005 (Mentougou Statistical Bureau, 2006). Fortunately, the coal mining was already under better control in order to protect ecoenvironment of Beijing region in recent years.

\subsection{Geological disasters}

Coal mine exploitation resulted in many cracks and subsidence of lands. The area influenced by land sinks covers about $218 \mathrm{hm}^{2}$, having serious potential damage. The coal mining directly destroyed about $6 \mathrm{~km}^{2}$ of the land surface, formed about $45 \mathrm{~km}^{2}$ of sink area, and among them, the subsidence in urban area is about $4 \mathrm{~km}^{2}$ (Mentougou Statistical Bureau, 2006).

\subsection{Influences on ground water resources}

Underground exploitation of coal mining and water drainage of mine pit brought about the decline of underground water level and resulted in a funnel area. It also changed the natural flow of ground water and its condition of supplying and draining. The decline of the underground water level led to the using and drinking water problem for residents in mining area and the neighbouring areas. The eluviation and penetration of mining wastes brought harmful effects to the regional water environment in the rainy seasons (Tiwary, 2001; Lacitignola et al., 2007).

\subsection{Effects on vegetation}

The exploitation of coal mine destroyed the vegetation around mountains, reduced the vegetation coverage and decreased the plant productivity (Yapp et al., 2010). The coal stacked, buried or pressured is not good for vegetation growth. Sulfur in coal dust affected the respiration of the crops. If it reacts with dew and rainwater, it will produce the acidic compound which wound burn the crop lamina and reduce the photosynthesis activity and crop outputs (Rodríguez and Arias, 2008).

\subsection{Loss of soil and water}

The soil and water loss due to coal mining in Mentougou district is serious. According to the National Third Time Soil Erosion Investigation finished in China in 2000, the area of soil and water loss in Mentougou district is $759 \mathrm{~km}^{2}$. Among them, the area of light degree is $610 \mathrm{~km}^{2}$, the area of middle degree is $149 \mathrm{~km}^{2}$. The modulus of soil erosion is $2000 \mathrm{t} / \mathrm{km}^{2}$ per year, the annual average soil erosion amounts to 2.9 million tons. The exploitation of coal and limestone is the main influencing factor that results in ecological and environmental problems in this area. Unreasonable stack of the coal mining residues is extremely apt to bring about the loss of soil and water (Paetzold et al., 2010).

\section{Research methodology}

\subsection{Structure of coal resources value system}

The structure of coal resources value system includes market value, labor value and ecological and environmental value (Fig. 1).

\subsection{Evaluation method for coal resources value}

Considering the data importance and its obtainment feasibility, through the general analysis, the authors decided that the evaluation indicators are as follows: loss due to solid waste occupancy, loss due to the coal mining sinks, loss due to land cultivation, soil and water loss, etc. (Table 1). The evaluation contents and methods for coal mining value in Montougou district of Beijing are listed in Table 2.

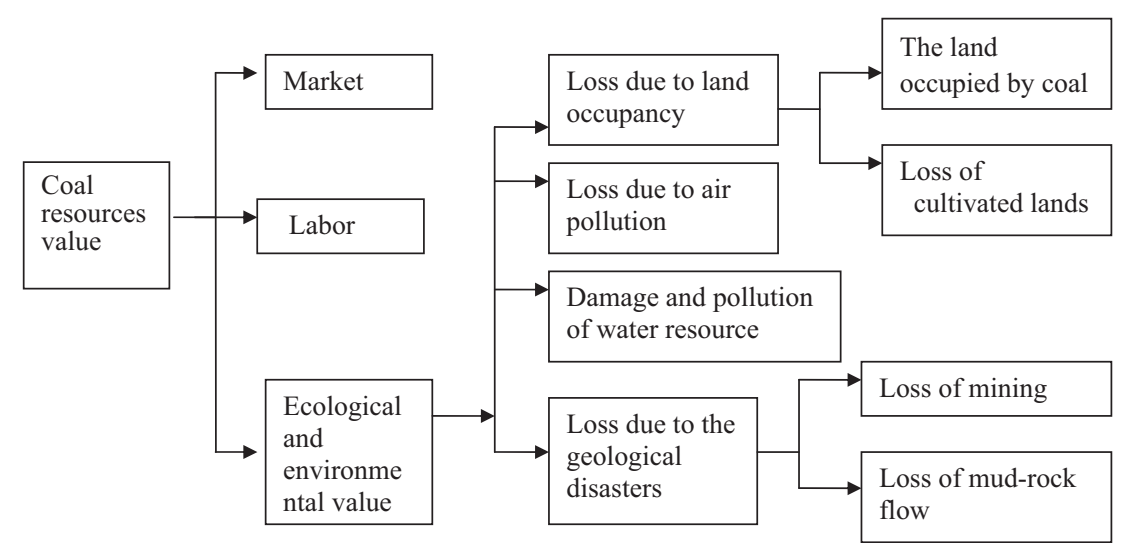

Fig. 1. The structure of coal resources value system. 
Table 1

Factor identification and feasibility analysis for coal mining on eco-environment.

\begin{tabular}{|c|c|c|c|c|c|c|c|}
\hline \multirow[t]{2}{*}{ Key elements } & \multirow[t]{2}{*}{ Various effects } & \multicolumn{3}{|c|}{ Affecting degree } & \multicolumn{3}{|c|}{ Evaluation feasibility } \\
\hline & & Heavy & Common & Light & High & Middle & Low \\
\hline \multirow[t]{3}{*}{ Solid wastes } & Loss due to coal wastes treatment & $\bullet$ & & & $\bullet$ & & \\
\hline & Loss due to lands occupied by coal wastes & 0 & & & 0 & & \\
\hline & Autoignition of coal waste & & $\bullet$ & & & - & \\
\hline \multirow[t]{3}{*}{ Geological environment } & Loss of migration in coal mining sinks & $\bullet$ & & & $\bullet$ & & \\
\hline & Mud-rock flow and sliding & & $\bullet$ & & & & $\bullet$ \\
\hline & Reclaimed fees for abandoned lands of coal mining & & 0 & & - & & \\
\hline \multirow[t]{3}{*}{ Water resource } & Waste water of coal processing & & 0 & & & & ○ \\
\hline & Loss of mining pit draining & & 0 & & & • & \\
\hline & Loss of water lack & - & & & - & & \\
\hline \multirow[t]{3}{*}{ Atmosphere } & Loss due to coal transportation and pollution & 0 & & & & & ○ \\
\hline & Cleaning charges & & 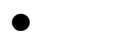 & & & & \\
\hline & Loss of the agriculture yield & & & 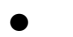 & & • & \\
\hline \multirow[t]{4}{*}{ Soil, biology and landscape } & Loss of biodiversity & & - & & & & - \\
\hline & Loss of water self-restraint & & 0 & & ○ & & \\
\hline & Loss of soil and water & $\bullet$ & & & & & \\
\hline & Landscape damage & & ○ & & & & ○ \\
\hline
\end{tabular}

Table 2

The evaluation contents and methods for coal mining value in Montougou district of Beijing.

\begin{tabular}{|c|c|c|}
\hline Key elements & Various effects & Evaluation methods \\
\hline \multirow[t]{2}{*}{ Solid waste } & Loss due to coal wastes treatment & Market Value Method \\
\hline & Loss due to lands occupied by coal wastes & Opportunity-Cost Method \\
\hline \multirow[t]{4}{*}{ Geological environment and coal mining sinks } & Loss of farmlands & Opportunity-Cost Method \\
\hline & Loss of water resource & Shadow-Project Method \\
\hline & Loss of abandoned land in mining area & Restoration-Cost Method \\
\hline & Loss of migration & Market Value Method \\
\hline \multirow[t]{2}{*}{ Soil, biology and landscape } & Loss of water self-restraint & Shadow-Project Method \\
\hline & Loss of soil and water & Shadow-Project Method \\
\hline
\end{tabular}

\section{Modeling formula and result analysis}

\subsection{Assessment of indirect economic value of coal mining}

Adopting the Market Value Method to calculate the economic value of coal mining, the calculation equation is as follows:

$V=(P-C) Q$

where $V$ is the indirect economic value of coal mining; $P$ describes the market price of coal resource; $C$ represents the cost of coal exploitation per unit; whereas $Q$ stands for the exploitation amount of coal mining.

The author uses the exchange rate of January 1, 2009 (683.66 Yuan $\mathrm{RMB}=\$ 100)$ to calculate the value in the following section. According to the investigation results, the coal exploitation in Mentougou district amounted to 0.15 billion tons since 1949 . The average selling price of $\$ 44.4 / \mathrm{t}$ of coal resource in 2006 and the mean cost of coal exploitation is $\$ 38.6 / \mathrm{t}$.

$V=(44.4-38.6) \times 0.15=\$ 870$ million

So, the direct economic value of coal exploitation in Mentougou district is about $\$ 870$ million.

Table 3

Loss caused by coal solid wastes.

\begin{tabular}{llr}
\hline Influence & Detailed effects & \multicolumn{1}{c}{ Loss $(\$)$} \\
\hline Solid wastes & Coal ash treatment & $31,448,380.1$ \\
& Coal stone treatment & $26,328,876.9$ \\
Farmlands & Loss of farmland cultivation & $40,888,745.9$ \\
& Loss fruit cultivation & $1,406,678,758.4$ \\
Water self-restraint value & Forest & $347,602,609.5$ \\
& Lawn & $32,791,153.5$ \\
Total & & $1,885,738,524.0$ \\
\hline
\end{tabular}

\subsection{Loss caused by coal solid wastes}

Using Market Value Method and Opportunity-Cost Method (Spangenberg and Settele, 2010; Trepel, 2010), The loss caused by coal solid wastes can be calculated by the following formula:

$V=S_{1}+S_{2}=\sum_{i=1}^{n} F_{i} C_{i}+\sum_{i=1}^{n} V_{i}$

where $V$ represents the total loss caused by coal wastes. $S_{1}$ is the treatment expense for all kinds of coal wastes; $S_{2}$ is the total loss caused by the occupancy of miming residue; $F_{i}$ is the amount of certain kind of solid waste in mining area; $C_{i}$ is deemed as the treatment expense of certain kind of solid waste per ton; $V_{i}$ stands for the loss caused by certain kind of mining residue occupancy. $i$ is the type number of different mining wastes.

Table 4

Loss caused by coal mining sinks.

\begin{tabular}{lc}
\hline Detailed effects & Loss $(\$)$ \\
\hline Loss of migration & $18,649,621.2$ \\
Loss of water resource & $1,608,986.9$ \\
Loss of farmlands & $83,374,776.9$ \\
Total & $103,633,385$ \\
\hline
\end{tabular}

Table 5

Value of water and soil loss.

\begin{tabular}{ll}
\hline Detailed effects & Loss $(\$)$ \\
\hline Soil nutrition loss & $305,853.8$ \\
Water loss & $112,629.1$ \\
Total & $418,482.9$ \\
\hline
\end{tabular}


Table 6

Total loss of ecosystem services resulted from the coal mining in Mentougou district of Beijing.

\begin{tabular}{|c|c|c|}
\hline Types of ecosystem services loss & Detailed effects & Value $(\$)$ \\
\hline \multirow[t]{4}{*}{ Loss due to the coal solid wastes } & Cost for coal ash treatment & $31,448,380.1$ \\
\hline & Cost for coal stone treatment & $26,328,876.9$ \\
\hline & Loss of farmlands and productivities & $40,888,745.9$ \\
\hline & Loss of fruit cultivation & $1,406,678,758.4$ \\
\hline \multirow{2}{*}{ Loss of water self-restraint value } & Forest & $347,602,609.5$ \\
\hline & Lawn & $32,791,153.5$ \\
\hline \multirow[t]{3}{*}{ Loss due to the coal mining sinks } & Loss of migration & $18,649,621.2$ \\
\hline & Loss of water resource & $1,608,986.9$ \\
\hline & Loss of farmlands & $83,374,776.9$ \\
\hline Reclamation of the abandoned lands & Cost for and reclamation & $11,400,000.0$ \\
\hline \multirow[t]{2}{*}{ Loss of the soil and water } & The nutrition loss & $305,853.8$ \\
\hline & Water loss & $112,629.1$ \\
\hline Total & & $2,001,190,392$ \\
\hline
\end{tabular}

According to the above equations, the loss caused by the coal solid wastes is as follows (Table 3 ).

\subsection{Loss caused by mining sinks}

Using Market Value Method, loss caused by mining sinks can be calculated by the following formula:

$V=V_{a}+V_{b}+V_{c}$

$V_{b}=H_{b} F_{b}$

where $V$ is the total loss resulted from mining sinks; $V_{a}$ describes the loss of water resource; $V_{b}$ is the loss due to people's migration; $V_{c}$ stands for the loss of farmlands and productivities; $H_{b}$ represents the number of families of migration; $F_{b}$ is deemed as the cost per family migration.

Loss of farmlands and productivities $\left(V_{c}\right)$ can be calculated by the following equation:

$V_{c}=\sum_{i=1}^{n} S_{i} M_{i}$

$S_{i}$ is the productivity of certain kind of crops per unit area; $M_{i}$ stands for the market price of the certain kind of crops.

According to above calculation, the loss caused by coal mining sinks is as follows (Table 4).

\subsection{Reclamation cost for the abandoned lands in coal mining area}

According to some relative research reports (Mentougou Statistical Bureau, 2006), the average direct cost of reclamation in different coal mining area in China is $\$ 13063.57 / \mathrm{hm}^{2}$. There are $8686 \mathrm{hm}^{2}$ coal mining areas abandoned in Mentougou district. Using Restoration Cost Method and Shadow-Project Method (Spangenberg and Settele, 2010; Trepel, 2010), if $\$ 13164.4$ is needed for per $\mathrm{hm}^{2}$, then the direct cost of reclamation is about $\$ 11.4$ million.

\subsection{Loss of water and soil}

The loss of soil nutrition includes the loss of organic matter and nutrient elements. Nutrient elements are N, P, K, and so on. Using Market Value Method and Shadow-Project Method, it can be calculated by the following formula.

$V=V_{1}+V_{2}$ where $V$ is the loss of the soil nutrition; $V_{1}$ is the loss of $\mathrm{N}, \mathrm{P}, \mathrm{K}$ elements; $V_{2}$ is the loss of the organic matter.

$V_{1}=Q_{i} \sum_{i=1}^{n} P_{1 i} P_{2 i} P_{3 i}$

$V_{2}=W P S$

where $Q_{i}$ describes the soil erosion (t/a); $P_{1 i}$ represents the N, P, K proportion in the soil (\%); $P_{2 i}$ is the proportion of pure $\mathrm{N}, \mathrm{P}, \mathrm{K}$ proportion in fertilizer (\%); $P_{3 i}$ stands for the selling price of fertilizers in the market $(\$) ; W$ is the amount of the organic matter; $P$ describes the selling price of the organic matter $(\$ / t) ; S$ represents the transforming parameter (\%).

The water loss can be calculated by Shadow-Project Method. The formula is as follows:

$V=E P$

$E=\frac{Q W}{K}$

where $V$ is the value of the soil water loss (\$); $E$ is the amount of water loss $\left(\mathrm{m}^{3}\right) ; P$ is the expense for constructing $1 \mathrm{~m}^{3}$ reservoir $(\$ /$ $\left.\mathrm{m}^{3}\right) ; \mathrm{Q}$ is deemed as the amount of soil erosion per year $(\mathrm{t}) ; W$ describes the proportion of water in volume in the soil; $K$ represents the volume weight of the soil $\left(t / \mathrm{m}^{3}\right)$. According to above calculation, the water and soil loss is as Table 5 .

\subsection{Total loss of ecosystem services resulted from the coal mining}

Throughout the estimation of the ecosystem services loss resulted from the exploration of coal resource mentioned above, the authors calculate that the total ecological and environmental loss caused by coal mining is about $\$ 2001$ million (Table 6).

\section{Concluding remarks}

As the study results, the value of mined coal resource in Mentougou district of Beijing was about $\$ 870$ million, at the same time, the corresponding loss of ecosystem services caused by coal mining was approximately $\$ 2001$ millions in the past 50 years. So, in fact, the indirect ecological and environmental loss resulted from coal exploitation was far more than its direct economic benefits. Fortunately, several years ago, the mining activity in Mentougou district had been forbidden by Beijing's government to protect the environment, improve people's life quality and promote the sustainable development in Beijing region.

The mined coal value and its corresponding loss of ecosystem services in Mentougou district of Beijing were evaluated in this 
research. Our data was just a rough estimate of the ecosystem service value. It can provide a decision-making basis for ecological restoration and compensation of natural resource for the authorities and governments in Beijing region as well as in other similar areas. Nevertheless, some parts of ecosystem service cannot be evaluated by economic value. From the ecological compensation aspect, it involves three levels: national level, district level and enterprise level. The ecological restoration and compensation from the national level mainly focuses on finance and policies; it mainly centralizes on investment, material and education from the district level; it mainly assembles in restoration projects from the enterprise level. Only through this approach, can the whole Beijing region develop toward a sustainable ecopolis.

\section{Acknowledgements}

This research was financially supported by the National Natural Science Foundation of China (70803050 and 30970507), the Key Supporting Project of Ministry of Science and Technology of PR China (2007BAC28B04, 2009BADC2B03 and 2008BAJ10B05), and the State Key Laboratory Project of Urban \& Regional Ecology (SKLURE2008-1-01).

\section{References}

Barbier, E.B., 1994. Valuing environmental functions: tropical wetlands. Land Economics 70, 155-173.

Costanza, R., d'Arge, R., de Groot, R., Farber, S., Grasso, M., Hannon, B., Laskin, R. Sutton, P., Van den Belt, M., 1997. The value of the world's ecosystem services and natural capital. Nature 387 (15), 253-260.

Daily, G. (Ed.), 1997. Nature's Service: Societal Dependence on Natural Ecosystems. Island Press, Washington, DC.

Daily, G., 1999. Developing a scientific basis for managing Earth's life support systems. Conservation Ecology 3 (2), 14.

Daily, G., Ellison, K., Myers, N., 2002. The New Economy of Nature. Island Press, Washington, DC.

Daily, G., Matson, P., 2008. Ecosystem services: from theory to implementation. Proceedings of the National Academy of Sciences of United States of America 105 (28), 9455.

Daily, G., Polasky, S., Goldstein, J., Kareiva, P., Mooney, H., Pejchar, L., Ricketts, T., Salzman, J., Shallenberger, R., 2009. Ecosystem services in decision making: time to deliver. Frontiers in Ecology and the Environment 7 (1), 21-28.

Editorial, 2010. Ecosystem services-bridging ecology, economy and social sciences. Ecological Complexity 7 (3), 257-259.

Gettings, M.E., Bultman, M.W., Fisher, F.S., 2004. A complex systems model approach to quantified mineral resource appraisal. Environmental Management 33 (1), 87-98.
Jørgensen, S.E., 2010. Ecosystem services, sustainability and thermodynamic indicators. Ecological Complexity 7 (3), 311-313.

Lacitignola, D., Petrosillo, I., Cataldi, M., Zurlini, G., 2007. Modelling socio-ecological tourism-based systems for sustainability. Ecological Modelling 206, 191-204.

Li, F., Hu, D., Liu, X.S., Wang, R.S., Yang, W.R., Paulussen, J., 2008. Comprehensive urban planning and management at multiple scales based on ecological principles: a case study in Beijing, China. The International Journal of Sustainable Development and World Ecology 15, 524-533.

Li, F., Liu, X.S., Hu, D., Wang, R.S., Yang, W.R., Li, D., Zhao, D., 2009. Measurement indicators and an evaluation approach for assessing sustainable urban development: a case study for China's Jining city. Landscape and Urban Planning 90 (3-4), 134-142.

Li, F., Wang, R.S., Paulussen, J., Liu, X.S., 2005. Comprehensive concept planning of urban greening based on ecological principles: a case study in Beijing, China. Landscape and Urban Planning 72 (4), 325-336.

Loomis, J., Kent, P., Strange, L., et al., 2000. Measuring the total economic value of restoring ecosystem services in an impaired river basin: results from a contingent valuation survey. Ecological Economics 33 (1), 103-117.

Ma, S.J., Wang, R.S., 1984. Social-economic-natural complex ecosystem. Acta Ecologica Sinica 4 (1), 1-9.

McNeely, J.A., Miller, K.R., et al., 1990. Conserving the World's Biological Diversity. Gland, Switzerland.

Mentougou Statistical Bureau, 2006. Mentougou Statistical Yearbook 2006. .

Norberg, J., 1999. Linking nature's service to ecosystems: some general ecological concepts. Ecological Economics 9, 83-202.

OECD, 1995. The Economic Appraisal of Environmental Protects and Policies: A Practical Guide. OECD, Paris.

Paetzold, A., Warren, P.H., Maltby, L.L., 2010. A framework for assessing ecological quality based on ecosystem services. Ecological Complexity 7, 273-281.

Pearce, D.W., Moran, D., 1994. The Economic Value of Biodiversity. Cambridge.

Pinto, R., Patrício, J., Neto, J.M., Salas, F., Carlos Marques, S., 2010. Assessing estuarine quality under the ecosystem services scope: ecological and socioeconomic aspects. Ecological Complexity 7 (3), 389-402.

Rodríguez, X.A., Arias, C., 2008. The effects of resource depletion on coal mining productivity. Energy Economics 30, 397-408.

Sandhu, H.S., Wratten, S.D., Cullen, R., 2010. The role of supporting ecosystem services in conventional and organic arable farmland. Ecological Complexity 7, 302-310.

Seidl, A.F., Moraes, A.S., 2000. Global valuation of ecosystem services: application to the Pantanal da Nhecolandi, Brazil. Ecological Economics 33 (1), 1-6.

Spangenberg, J.H., Settele, J., 2010. Precisely incorrect? Monetising the value of ecosystem services. Ecological Complexity 7, 327-337.

Tiwary, R.K., 2001. Environmental impact of coal mining on water regime and its management. Water, Air, and Soil Pollution 132, 18.

Trepel, M., 2010. Assessing the cost-effectiveness of the water purification function of wetlands for environmental planning. Ecological Complexity 7, 320-326.

Wang, R.S., 1986. High Efficiency and Harmonious Relationship - The Principles and Methodology of Urban Ecological Regulation. Hunan Educational Press, Changsha.

Wang, R.S., Hu, D., Wang, X.R., Tang, L.J., 2004. Urban Eco-service. Chinese Meteorological Press, Beijing, pp. 20-29 (in Chinese).

Wang, R.S., Li, F., Paulussen, J., 2010. Conjugate ecopolis planning: balancing ecoservice and human well being in Beijing. Annals of the New York Academy of Sciences 1195, E131-E144.

Yapp, G., Walker, J., Thackway, R., 2010. Linking vegetation type and condition to ecosystem goods and services. Ecological Complexity 7, 292-301. 